\title{
Computers, Fax Machines and Wages in Canada: What Really Matters?
}

\author{
by \\ René Morissette* and Marie Drolet**
}

No. 126

\begin{abstract}
11F0019MPE No. 126
ISSN: 1200-5223

ISBN: 0-660-17607-6
\end{abstract}

Price: $\$ 5.00$ per issue, $\$ 25.00$ annually

Business and Labour Market Analysis

24, R.H. Coats Building, Ottawa, K1A 0T6

*Statistics Canada (613) 951-3608

**Statistics Canada (613) 951-5691

Facsimile Number: (613) 951-5403

E-mail: moriren@statcan.ca

drolmar@statcan.ca

October 1998

This paper represents the views of the author and does not necessarily reflect the opinions of Statistics Canada. 



\section{Table of Contents}

I. Introduction _ 3

II. New Technologies and Wages: Recent Evidence __ 4

II.1 Manufacturing sector __ 4

II.2 Whole economy — 5

III. The Data___ 6

IV. Results__ 7

V. Discussion — 9

VI. Summary and Conclusions ___ 11

Bibliography__ 25 


\section{Abstract}

Controlling for observable worker attributes, we find that computer use is associated with a wage premium of at most 14\%. Following Dinardo and Pischke (1997), we examine the wage premium associated with other tools used on the job. While these authors find a significant wage premium for the use of pencils or for sitting down while working, we find a substantial and robust wage premium for the use of a fax machine. Using a variety of reasonable specifications of wage equations including both a computer use indicator and a fax use indicator, we consistently find a stronger effect for fax machines than for computers. Along with Dinardo and Pischke (1997), we argue that workers who use computers earn more than other employees not because of their computing skills per se, but rather because they have more other unobserved skills - innate or learned through school - than other employees.

Key words: Wages, Earnings inequality, Computer, Technological changes. 


\section{Introduction}

When one examines the time path of wages over the last twenty-five years in Canada, three facts emerge. First, earnings inequality rose substantially during the eighties (Morissette, Myles and Picot, 1995: Beach and Slotsve, 1994), as it did in many OECD countries. Second, real wages of young males have dropped markedly. For instance, between 1981 and 1995, real annual earnings of men aged 25-34 employed full year full-time fell 10\% while those of their counterparts aged 45-54 rose $3 \%$. Third, the wage gap between university graduates and high school graduates rose modestly (Freeman and Needels, 1991: Bar-Or et. al., 1995: Morissette, 1995).

Skill-biased technical changes have been used as one explanation of these trends (e.g. Bound and Johnson, 1992) ${ }^{1}$. According to this view, the introduction of new technologies, exemplified by the computer revolution, has increased the demand - and thus the wages - of highly skilled workers and has caused an increase in earnings inequality.

Because of the scarcity of microdata combining information on workers' wages and their use of advanced technologies, the direct examination of the relationship between wages and new technologies has been the subject of relatively few studies. Using establishment data for the manufacturing sector, Dunne and Schmitz (1995) and Baldwin et al. (1997) show that establishments which use computer-based technologies pay higher wages than other establishments. However, Doms, Dunne and Troske (1997) show that while there is a positive correlation between plant-level wages and technology use, there is little correlation between changes in plant-level wages and technology adoption.

Krueger (1993) finds that U.S. workers who use computers on the job earn 10-15\% more than other American employees. In a provocative paper, Dinardo and Pischke (1997) use West German data to show that a significant wage premium is also observed for the use of pencils on the job. Since pencils are unlikely to have changed the wage structure, these authors argue that "these findings cast some doubt on the literal interpretation of the computer use wage differential as reflecting true returns to computer use or skill". In other words, workers who use computers could receive higher wages because they are 'better' than other employees or because their employers have different unobserved characteristics. Using longitudinal data, Entorf and Kramarz (1996) test this proposition and find that workers who use computers indeed have more unobserved abilities.

To our knowledge, no Canadian study has yet examined the association between wages and computers using worker data. This paper attempts to answer two questions: First, do workers who use computers earn a higher wage? Second, do higher wages represent returns to computer use or unobserved worker heterogeneity?

We use data from the 1994 General Social Survey (GSS). After controlling for observable worker attributes, we find that computer use is associated with a wage premium of, at most, $14 \%$.

1 The growth of international trade, institutional changes (e.g. de-unionization, decline in the real value of the minimum wage) and changes in the relative supply of university graduates are other potential factors underlying the growth of earnings inequality. See the well-known survey by Levy and Murnane (1992). 
Following Dinardo and Pischke (1997), we examine the wage premium associated with other tools used on the job. While these authors find a significant wage premium for the use of pencils or for sitting down while working, we find a substantial and robust wage premium for the use of a fax machine. Using a variety of reasonable specifications of wage equations including both a computer use indicator and a fax use indicator, we consistently find a stronger effect for fax machines than for computers. Along with Dinardo and Pischke (1997), we argue that workers who use computers may earn more than other employees mainly because they have more unobserved talents than other employees.

In section II, we review the recent empirical studies providing direct evidence on the relationship between wages and new technologies. Next, we present the data set used in the paper (section III). We document the relationship between wages and computer use in section IV. We discuss these results in section $\mathrm{V}$ and provide a summary and concluding remarks in section VI.

\section{New Technologies and Wages: Recent Evidence}

\section{II.1 Manufacturing sector}

Baldwin et al. (1997) combine data from the 1989 Survey of Manufacturing Technology (SMT), the Census of Manufactures, and the 1993 Survey of Innovation and Advanced Technology to study how wages in Canadian establishments using advanced technologies compare to those of other establishments.

First, they show that the use of new technologies is unequally distributed across different stages of the production process (i.e. design and engineering, fabrication and assembly, automated material handling, inspection and communications, manufacturing information systems and integration and control). Thus, in 1989, $79 \%$ of shipments in manufacturing originated from plants using advanced techniques in inspection and communications while only $47 \%$ of shipments were produced by establishments using advanced techniques in fabrication and assembly. Second, at all stages of the production process, the adoption of new technologies increases the skill requirements of workers. Third, this increase in skill requirements is associated with an increase in employers' training costs. Fourth - and more importantly - after controlling for relevant plant characteristics, establishments using advanced technologies generally pay higher wages than other establishments.

The wage premium differs depending on the type of technology used. It varies between $6 \%$ and $11 \%$ for establishments using new techniques in design and engineering, inspection and communications and integration and control $^{2}$. However, the wage differences are small in establishments using advanced technologies for automated material handling (3\%) or nonexistent in those establishments using advanced technologies in fabrication and assembly $(-3 \%)$.

This suggests a dichotomy between repetitive tasks, on one hand, and those requiring strong conceptual/analytical skills. More precisely, the wage premium appears to be higher in parts of the

2 This is the wage premium resulting from a multivariate analysis, i.e. after controlling for plant characteristics such as capital intensity, degree of diversification, size, foreign ownership, etc. 
production process which make intensive use of workers' problem solving skills than in those parts involving routine tasks leaving workers little autonomy.

Using U.S. data from the 1988 Survey of Manufacturing Technology and the 1987 Census of Manufactures, Dunne and Schmitz (1995) also find that establishments using computer-based technologies pay higher wages than other establishments.

The positive correlation between plant-level wages and technology use may reflect two types of causality. On one hand, the act of adoption of new technologies may raise labour productivity and lead workers to receive higher wages. On the other hand, firms with a workforce with relatively high unobserved abilities - and thus relatively high labour productivity and wages - may be more likely to adopt new technologies than other firms. In this case, the causality runs from the quality of the workforce to the adoption of new technologies. In this scenario, changes in plant-level wages should be uncorrelated with technology adoption.

Along with Baldwin et al. (1997) and Dunne and Schmitz (1995), Doms, Dunne and Troske (1997) find, in cross-sectional data, that plants using new technologies tend to pay higher wages. However, using longitudinal data, they show that changes in plant-level wages are not correlated with technology adoption. They interpret this finding as reflecting the fact that plants adopting new factory automation technologies may have more skilled workforces both before and after adopting these technologies.

\section{II.2 Whole economy}

In the three aforementioned studies, the establishment is the unit of analysis. Krueger (1993) is the first study to examine the relationship between wages and new technologies at the worker level. Krueger (1993) uses data from the Current Population Survey to show that after controlling for observable worker characteristics, employees who use a computer on the job earn 10-15\% more than other employees. Furthermore, he finds that the expansion in computer use explains between one-third and one-half of the growth in the returns to education observed in the second half of the eighties in the United States. He argues that "these results provide support for the view that technological change - and in particular the spread of computers at work - has significantly contributed to recent changes in the wage structure" $(1993,55)$.

Dinardo and Pischke (1997) challenge this view using data from the West German Qualification and Career Survey. These authors show that in a regression which includes standard regressors and dummy variables for computer use, for the use of pencils and for whether or not an employee is sitting down while working, the last two variables are both empirically and statistically significant. They argue that pencils are unlikely to have changed the wage structure and that the positive correlation between wages and computer use found by Krueger (1993) may simply be due to the fact that computer users are better workers than other employees or they hold jobs requiring more skills.

To determine whether the computer use wage premium reflects a causal relationship between computers and wages or unobserved worker heterogeneity, one needs longitudinal data. If computer use leads to higher wages, then workers who move from a job in which they did not use a computer to another job in which they do use a computer, all other things being equal, should exhibit higher 
wage increases than all other employees. Otherwise, the positive correlation between wages and computer use observed in a cross-section may simply reflect differences in unobserved abilities.

Entorf and Kramarz (1996) use French longitudinal data and show that both worker productivity and unobserved abilities play a role in wage determination. Specifically, they find that workers who use computers have more unobserved talents than other individuals but that the use of computers raise workers' wages in subsequent years. Using longitudinal data from the United Kingdom, Bell (1996) finds that most of the correlation observed between wages and computer use in crosssectional data remains in a first-difference wage equation.

Entorf and Kramarz (1996) also distinguish three types of new technologies, those giving workers a high, average or small level of autonomy. Along with Baldwin et al. (1997), they show that in crosssectional data, the wage premium for using advanced technologies depends on the type of technology used. For instance, workers using new techniques involving a high degree of autonomy earn $16 \%$ more than workers who do not use advanced technologies. In contrast, the wage premium is non-existent for employees using new techniques involving little autonomy (e.g. robots). Once again, this highlights the need to distinguish techniques involving repetitive tasks from those requiring workers' analytical skills.

\section{The Data}

In this paper, we use the 1994 General Social Survey (GSS) to examine the relationship between wages and computer use.

The 1994 General Social Survey is the first Canadian survey which collects information both on workers' wages and on their use of a computer in their job ${ }^{3}$. Individuals are asked whether they use computers such as mainframes, personal computers or word processors in their job. In addition, respondents are asked whether, in the past twelve months, they have used a fax machine, a photocopier and a telephone answering machine. ${ }^{4}$ The sample we select for this survey includes paid workers aged 15-64 who were not full-time students at the time of the interview and who were at work during the reference week. Of all these individuals, $16 \%$ did not report their wage rates. We exclude these non-respondents ${ }^{5}$. The remaining sample contains 1,824 men and 1,754 women.

3 The 1989 General Social Survey collected information on computer use and on personal income but not on earnings.

4 Appendix 3 contains the actual questions on computers, fax machines and wages taken from the General Social Survey of 1994.

5 Compared to non-respondents, respondents are generally younger, less educated but are also more often employed in large firms and in unionized jobs. See Table A1 of Appendix 1 for a comparison of the profiles of these two groups. These differences may have an impact on the computer use wage premium. For instance, results not shown here indicate that the difference in raw log wages between computer users and non-users is small for younger workers and unionized workers. As a result, the fact that these groups are over-represented in our sample may bias downwards the coefficient for computer use. 


\section{Results}

One in two workers use computers on the job (Table 1). Professionals and highly educated workers employed full-time in large firms are the most likely to use computers. For instance, only $20 \%$ of employees with less than high school use computers, compared to roughly $80 \%$ of university graduates. Surprisingly, young workers tend to use computers less often than their older counterparts. This is partly due to the fact that young workers are disproportionately represented in services-related occupations and in small firms, where the incidence of computer use is relatively low. In fact, when controls for occupation and firm size are added to a set of regressors which includes age and education (in a logit model), the probability of using a computer no longer varies across age groups for male workers (Appendix 2, Table A1, column 4). However, female employees aged 15 to 24 are still less likely to use computers than their counterparts aged 25 to 44 .

Roughly $40 \%$ of workers have used a fax machine at least once a week for the last twelve months (Table 1). Fax machines tend to be used most often by males who are professionals and managers and by women who hold clerical occupations (e.g. secretaries). Not surprisingly, blue-collar workers very rarely use fax machines. Similarly, young employees are not frequent fax users. Results not shown here indicate that these qualitative conclusions hold in a logit model where the probability of using a fax machine is assumed to depend on age, education, occupation and firm size.

In the raw data, the computer use wage premium is - at least for men - virtually indistinguishable from the fax use wage premium. Men who use computers earn $46 \%$ more than those who do not use computers; men who use fax machines at least once a week earn $44 \%$ more than other male employees (Table 2). The comparable numbers are $27 \%$ and $19 \%$ for women.

In Table 3 we provide an international comparison of the effect of computer use on pay. As reported in Dinardo and Pischke (1997) the raw log wage differential for Germany is somewhat lower than those reported by Krueger (1993) for the United States. The raw log wage differential for Canada is 0.30. We report estimates from OLS wage regressions that include a computer dummy among other covariates for Canada, United States (Autor, Katz and Krueger 1997) and Germany (Dinardo and Pischke, 1997). The coefficient on computer use is comparable across countries and varies between 16 and $20 \log$ points.

In the first panel of Table 4, we regress the natural logarithm of hourly wages on a traditional vector of regressors $^{6}$ as well as on a dummy variable which equals 1 if a worker uses a computer, 0 otherwise. The resulting wage premium for computer use equals $14 \%$ (i.e. $\exp (0.133)$-1) for men and $11 \%(\exp (0.103)-1)$ for women ${ }^{7}$. We then replace the computer use dummy variable by a dummy variable for fax use. When this is done, we find a wage premium of roughly $19 \%$ for male

6 The vector of explanatory variables includes an intercept, age, age squared, tenure, tenure squared, four education dummies, union status, one dummy variable for part-time jobs, seventeen industry dummies, six region dummies and four dummies for firm size.

7 The careful reader will have noted that the computer use wage premium is lower in Table 4 than it is in Table 3 . This is due to the inclusion of additional regressors for industry and firm size in Table 4. 
and female fax users. Both the computer use wage differential and the fax use wage differential decline slightly when we add 33 controls for occupation.

The substantial wage difference observed for fax users could simply reflect multicollinearity between computer use and fax use. To assess whether this is the case, we proceed in two steps. First, following Dinardo and Pischke (1997), we enter both tools in the wage equation (Table 4, Panel II). When we do so, the wage premium for computer use drops to $9 \%$ for men and is no longer significant for women. In contrast, the wage premium for fax use never falls below $15 \%$. This holds whether or not we add controls for occupations. Second, we re-estimate the fax use wage premium (including occupation dummies) for the sub-sample of workers who do not use computers. The fax use wage difference for this subgroup is similar to that for the whole population: it equals $15 \%$ for women and $20 \%$ for men (Table 5, columns 1 and 4). Clearly, the positive correlation between fax use and wages is not simply due to multicollinearity between the utilization of computers and fax machines.

Our controls for occupation are fairly broad and the higher wages of fax users could reflect differences in wages across more narrowly defined occupations. Put simply, many fax users could be high-rank executives. To check this possibility, we add to our wage equation (which includes controls for computer use, fax use and occupations) an additional set of dummy variables for high skilled worker, for top manager, for participating in the planning of the activities of the entire company, and for a supervisor. We also include the number of employees supervised (Table 6). With the most detailed specification, the wage premium for computer use falls to $6 \%$ for men and remains not significant for women. However, the fax use wage premium moves from $16 \%$ to $12 \%$ for men and from $15 \%$ to $14 \%$ for women. Thus, at least for men, part of the wage premium associated with fax use appears to be to a high-rank executive effect. This conclusion holds when we restrict our analysis to workers who do not use computers (Table 4, columns 2-3 and 5-6).

In a further attempt to control for worker heterogeneity, we have added regressors such as the highest education level of the mother and of the father (both added separately and together), the number of months worked over the last 5 years and the number of promotions received over the last five years. These experimentations leave the numbers of Table 4 and of column 12 of Table 6 virtually unchanged.

In Table 7, we show the percentage of workers who have used various computer applications in the past twelve months. The computer use wage premium differs depending on the type of application used (Table 8). After controlling for occupations, male workers who, in the past 12 months, have used computers for data analysis or to access internet earn more than those involved in data entry or record keeping. Furthermore, women doing word processsing receive higher wages than those involved in data entry and record keeping. Surprisingly, there is - for men - a positive correlation between using computer games and wages. We interpret this as evidence that the computer use wage premium does not necessarily reflect a causal effect of computer use on wages.

Our findings mirror those of Dinardo and Pischke (1997) who find robust wage differences for the use of pencils and for sitting down while working. Because fax machines and pencils are unlikely to have altered the productivity of workers significantly, both sets of results suggest that the positive correlation between fax use/pencils and wages may reflect other unobserved talents or abilities that are not well measured by existing data sets. For instance, managers who use fax machines may have more ability to establish networks or greater problem-solving skills than other managers. If the correlation between fax use and wages reflects a selection effect rather than a causal effect running 
from fax use to productivity and then wages, then - as Dinardo and Pischke (1997) argue - the positive correlation between computer use and wages may also reflect a selection effect. In other terms, the computer use wage premium observed in wage equations does not necessarily provide direct evidence that the increase in real wages of highly skilled workers observed in the eighties was caused by the introduction of computers in the workplace.

\section{Discussion}

The main message of this paper is that one has to be very careful about the interpretation of the regression coefficient obtained for computer use in a cross-sectional wage equation. This warning holds for both individual and plant level wage data. As Entorf and Kramarz (1996), Dinardo and Pischke (1997) and Doms, Dunne and Troske (1997) argue, part of the positive correlation between individual (plant-level) wages and computer use (new technologies) observed in a cross-sectional individual (plant-level) wage equation may reflect higher worker's unmeasured abilities as well as unmeasured characteristics of employers such as managerial ability. The evidence presented in this paper, in which we consistently find a strong correlation between wages and the use of fax machines, suggests that such selection effects are likely to be important.

As Autor, Katz and Krueger (1997) argue, the existence of a computer use wage premium in a cross-sectional wage equation is neither a necessary nor a sufficient condition to infer that the introduction of computers have changed the wage structure and increased earnings inequality. On one hand, a positive association between wages and computer use may simply reflect selection effects. On the other hand, the absence of correlation between wages and computer use does not imply that the introduction of computers has not altered the wage structure.

To see this, assume the economy consists of two types of workers, some who are unskilled and some who have, say, problem-solving skills. If problem-solving skills and capital are complementary, then a decrease in computer costs will increase the demand for capital and for these skills. Put simply, the demand for workers with problem-solving skills will shift rightwards, inducing wage increases for these workers. To attract such workers, firms will have to pay them higher wages, whether these workers use computers or not. Hence, even though the introduction of computers has, in this example, increased the relative wages of skilled workers and caused an increase in earnings inequality, an econometrician using cross-sectional data to estimate a wage equation and having sufficient controls for problem-solving skills would find no correlation between wages and computer use (Autor, Katz and Krueger, 1997, p. 18).

The appropriate test for whether the introduction of computers or new technologies raises wages by increasing labour productivity requires the use of longitudinal data. If such a causality exists, then changes in the incidence or intensity of computer use should be positively correlated with changes in labour productivity and with changes in wages. In contrast, if the positive computer use wage premium simply reflects unmeasured characteristics of workers or firms, then no correlation should be observed. This is what Entorf and Kramarz (1996) and Doms, Dunne and Troske (1997) find, using worker data and plant-level data, respectively.

Yet this test is not flawless. In a first-difference wage equation, the regression coefficient for the change in the incidence/intensity of computer use may be biased. This could happen if the 
introduction of computers increased the demand for a skill which is not exclusively linked to the use of a computer. In the previous example, assume that computers did not exist at time $t$ and that the introduction of computers at time $t+1$ caused a $10 \%$ increase in the real wages of all workers who have problem-solving skills and left unchanged the real wages of unskilled workers. While all workers who start using a computer at time $\mathrm{t}+1$ have problem-solving skills and thus enjoy a $10 \%$ wage increase, workers who use computers in neither period include both those who are unskilled and some workers with problem-solving skills. As a result, the average wage increase of non-users in both periods - which is a weighted average of the wage increases for skilled and unskilled workers - will be positive but less than $10 \%$. Hence, the regression coefficient for the change in the incidence/intensity of computer use will, in that example, be biased downwards ${ }^{8}$.

Furthermore, if the computer use wage premium observed in cross-sectional data reflects a return to some unobserved skill whose price increases over time, then the assumption of time-invariant fixed effects will be inappropriate (Dinardo and Pischke, 1997, p. 302). If so, first-differencing a wage equation might yield a positive regression coefficient for the change in the incidence of computer use. Yet, if the time interval considered is relatively long, that coefficient may simply reflect the fact that workers who possess this unobserved skill - and have started using computers - have enjoyed higher-than-average wage growth because the return to this skill has risen over time. In other words, a positive regression coefficient for the change in incidence of computer use may reflect: 1) a true return to computer skill or use 2) the growth in the return to some unobserved skill caused by the introduction of computers (e.g. a growing return to problem-solving skills in the previous example), and/or 3) the growth in the return to some unobserved skill not caused by the introduction of computers.

The distinction has important implications. If the coefficient for the change in incidence of computer use reflects true returns to computer skills, then training workers to raise their computing skills should increase their wages, increase the supply of computing skills on the market and thus eventually reduce earnings inequality. On the other hand, if it reflects the growth in the return to some unobserved skills caused by the introduction of computers, then identifying these skills and determining whether or not they can be learned from schools or training is crucial to improve the position of low-skilled workers. As Bartel and Sicherman (1997) point out, if these skills result from abilities that are truly innate and cannot be learned in school, the wage differences related to technological changes should not disappear over time. If these skills can be learned in school or through some type of training, then policy interventions aimed at providing the appropriate set of skills could succeed in increasing the wages of low-skilled workers and in reducing earnings inequality.

The difficulty of giving a clear interpretation to regression coefficients from longitudinal data suggests looking at indirect evidence on the link between computer use and wages. Greenan and Mairesse (1996) use linked employer-employee data for France and find that after controlling for capital intensity and establishment size, computer use is positively correlated with labour productivity. Allen (1996) finds that between 1979 and 1989, the returns to schooling rose the most

8 Because measurement error is more serious for wage changes than for wage levels (Bound and Krueger, 1991), a first-difference wage equation will produce less reliable parameter estimates than a cross-sectional wage equation. On the other hand, as long as unobserved abilities matter, the cross-sectional wage equation will suffer from the omitted variable bias. 
in the industries where R\&D intensity grew most rapidly and used high-tech capital most intensively. Autor, Katz and Krueger (1997) show positive correlations between indicators of computer use and the growth in the utilization of college workers and nonproduction workers. Gera et al. (1997) pool cross-sectional and time-series data on industries for the 1971-1993 period and find a significant relationship between investments in information technologies and labour productivity growth for Canada. ${ }^{9}$ Whatever the underlying causality is, all these studies suggest a positive relationship between computer use, on one hand, and indicators of labour productivity (Greenan and Mairesse, 1996; Gera et al., 1997) or indicators of demand for high-skilled workers (Allen, 1996; Autor, Katz and Krueger, 1997), on the other hand.

\section{Summary and Conclusions}

In this paper, we have examined the association between wages and computer use. Our main findings can be summarized as follows:

1) depending on the specifications of wage equations, male computer users earn $6-14 \%$ more than non-users. For women, the computer use wage premium either is not significant or reaches a maximum of $11 \%$;

2) depending on the specifications of the wage equations, male fax users earn 11-20\% more than non-users. For women, the fax use wage premium varies between $13 \%$ and 19\%;

3) in all specifications involving both a computer use indicator and a fax use indicator, the use of fax machines has a larger effect than the use of a computer;

Our experiments show that wages of computer users are generally higher than wages of non-users. However, the fact that we consistently find a strong association between fax use and wages leads us - along with Dinardo and Pischke (1997) - to question the idea that this correlation reflects a true return to computer use or to computer skill. Because it is very unlikely that fax machines have altered the wage structure, the fax use wage premium probably reflects unobserved characteristics of workers and firms. If such selection effects are important for fax machines, they could be equally important for computers. Unsurprisingly, we believe that fax machines do not matter, i.e. have not caused a change in the wage structure. Computers may have altered the wage structure and increased earnings inequality. Whether not this is the case can hardly be judged with cross-sectional data. Even though the interpretation they convey may not be unique, longitudinal data are better suited for this task.

9 Gera et al. (1997) estimate their model with U.S. data and find that the relationship between investment in information technologies and labour productivity growth, although positive, is less robust than for Canada. 
Table 1: Percentage of workers who use computers at work and percentage of workers who use fax machines at least once a week, 1994

\begin{tabular}{|c|c|c|c|c|c|c|}
\hline & \multicolumn{3}{|c|}{ Computers } & \multicolumn{3}{|c|}{ Fax Machines } \\
\hline & All & Men & Women & All & Men & Women \\
\hline All workers & 50.3 & 45.4 & 56.1 & 38.9 & 35.6 & 42.8 \\
\hline \multicolumn{7}{|l|}{ Age } \\
\hline $15-24$ & 36.7 & 29.3 & 44.3 & 23.3 & 16.8 & 30.0 \\
\hline $25-34$ & 52.2 & 44.8 & 62.3 & 40.5 & 35.2 & 47.7 \\
\hline $35-44$ & 56.6 & 51.3 & 62.4 & 42.2 & 40.9 & 43.6 \\
\hline $45-54$ & 48.9 & 46.5 & 51.4 & 42.2 & 39.1 & 45.5 \\
\hline $55-64$ & 44.4 & 46 & 42.6 & 35.1 & 35.0 & 35.2 \\
\hline \multicolumn{7}{|l|}{ Education } \\
\hline less than high school & 19.9 & 18.1 & 23.1 & 14.9 & 13.6 & 17.2 \\
\hline high school completed & 48.0 & 38.7 & 58.7 & 39.3 & 29.9 & 50.0 \\
\hline post-secondary & 52.7 & 48.8 & 56.6 & 43.4 & 40.6 & 46.1 \\
\hline university graduate & 79.1 & 83.7 & 74.4 & 53.8 & 63.1 & 44.3 \\
\hline \multicolumn{7}{|l|}{ Full-time job? } \\
\hline yes & 52.2 & 46.3 & 60.4 & 41.3 & 36.6 & 47.7 \\
\hline no & 36.6 & 26.1 & 39.3 & 21.4 & 13.8 & 23.4 \\
\hline \multicolumn{7}{|l|}{ Occupation } \\
\hline Professionals and managers & 70.3 & 79.0 & 63.0 & 56.4 & 68.1 & 46.4 \\
\hline Clerical & 73.5 & 57.9 & 77.3 & 56.4 & 34.8 & 61.8 \\
\hline Sales \& Services & 32.4 & 39.6 & 26.2 & 25.0 & 29.3 & 21.4 \\
\hline Blue-collar & 24.0 & 23.9 & 24.2 & 16.0 & 7.9 & 13.1 \\
\hline \multicolumn{7}{|l|}{ Firm size } \\
\hline 1-19 employees & 32.7 & 20.6 & 43.8 & 31.3 & 22.5 & 39.5 \\
\hline 20-99 employees & 41.6 & 36.6 & 48.5 & 37.1 & 37.2 & 37.1 \\
\hline 100-499 employees & 48.4 & 41.9 & 56.8 & 42.8 & 36.7 & 50.6 \\
\hline 500 employees or more & 65.4 & 62.5 & 68.9 & 44.3 & 41.7 & 47.5 \\
\hline Sample size & 3,578 & 1,824 & 1,754 & 3,578 & 1,824 & 1,754 \\
\hline
\end{tabular}

Source : General Social Survey of 1994

Table 2: Average hourly wages of computer users and fax users, 1994

Men Women

All

Worker uses computer?

\begin{tabular}{|c|c|c|c|}
\hline (1) yes & 21.56 & 15.43 & 18.39 \\
\hline (2) no & 14.77 & 12.11 & 13.68 \\
\hline$(3)=(1) /(2)$ & 1.46 & 1.27 & 1.34 \\
\hline \multicolumn{4}{|c|}{ Worker uses a fax machine? } \\
\hline (1) yes & 22.19 & 15.40 & 18.73 \\
\hline (2) no & 15.45 & 12.90 & 14.34 \\
\hline$(3)=(1) /(2)$ & 1.44 & 1.19 & 1.31 \\
\hline
\end{tabular}


Table 3: International comparison of the effect of computer use on pay

\begin{tabular}{|c|c|c|c|c|c|c|}
\hline \multirow[t]{2}{*}{ Country } & \multirow{2}{*}{$\begin{array}{c}\text { Canada } \\
1994\end{array}$} & \multicolumn{3}{|c|}{ United States } & \multicolumn{2}{|c|}{ Germany } \\
\hline & & 1984 & 1989 & 1993 & 1985-86 & 1991-92 \\
\hline $\begin{array}{l}\text { I. Computer use } \\
\% \text { of workers using computers }\end{array}$ & 50.3 & 25.1 & 37.4 & 46.6 & 18.5 & 35.3 \\
\hline $\begin{array}{l}\text { II. Wages } \\
\text { Raw log wage differential* }\end{array}$ & 0.30 & 0.28 & 0.33 & n.a. & 0.24 & 0.29 \\
\hline $\begin{array}{l}\text { OLS regression } * * \\
\text { Coefficient on computer use } \\
\text { Standard error }\end{array}$ & $\begin{array}{c}0.200 \\
(0.017)\end{array}$ & $\begin{array}{c}0.171 \\
(0.008)\end{array}$ & $\begin{array}{c}0.188 \\
(0.008)\end{array}$ & $\begin{array}{c}0.204 \\
(0.008)\end{array}$ & $\begin{array}{c}0.157 \\
(0.007)\end{array}$ & $\begin{array}{c}0.171 \\
(0.006)\end{array}$ \\
\hline Number of observations & 3,578 & 13,335 & 13,379 & 13,305 & 22,353 & 20,042 \\
\hline Data & $\begin{array}{l}\text { General Social } \\
\text { Survey of } 1994\end{array}$ & Curre & Populatic & urvey & $\begin{array}{l}\text { Qualific } \\
\text { Caree }\end{array}$ & $\begin{array}{l}\text { ion and } \\
\text { urvey }\end{array}$ \\
\hline Authors & $\begin{array}{l}\text { Morissette and } \\
\text { Drolet (1998) }\end{array}$ & Autor, $\mathrm{I}$ & $\mathrm{z}$ and $\mathrm{Kr}$ & er (1997) & $\underset{(1}{\text { Dinardo }}$ & $\begin{array}{l}\text { 1 Pischke } \\
\text { 7) }\end{array}$ \\
\hline
\end{tabular}

Note: $* \quad$ The raw low wage differential for the United States is taken from Krueger (1993).

Note: ** The dependent variable is log hourly wages. Models for the United States and Germany include an intercept, a dummy for part-time, large city/SMSA status, female, married, female*married, years of schooling, experience, experience squared. Regressions for the United States also include dummies for race, veteran status, union membership and three regions. Regressions for Germany also include a dummy for civil servants. The regression for Canada includes an intercept, a dummy for part-time, female, married, female married, 4 education levels, age, age squared, union status and 6 regions. 
Table 4: $\quad$ OLS Regressions for the Effect of Computers and Fax Machines on Pay

I.

Occupation

Indicators

Computer

Adjusted R square

Fax

Adjusted R square

Sample size

II.

Occupation

Indicators

Computer

Fax

Adjusted R square

Sample size

0.179

0.166

(7.66)

$0.5044 \quad 0.5307$

1,824

1,824

\section{Tools entered together}

\begin{tabular}{cccc}
\multicolumn{2}{c}{ Men } & \multicolumn{2}{c}{ Women } \\
no & yes & no & yes \\
& & & \\
0.084 & 0.086 & 0.044 & 0.043 \\
$(3.86)$ & $(3.82)$ & $(1.51)$ & $(1.40)$ \\
& & & \\
0.154 & 0.147 & 0.156 & 0.144 \\
$(7.20)$ & $(6.63)$ & $(5.57)$ & $(4.81)$ \\
& & & \\
0.5082 & 0.5343 & 0.3467 & 0.3744 \\
1,824 & 1,824 & 1,754 & 1,754 \\
\hline
\end{tabular}

All regressions also include an intercept, age, age squared, tenure, tenure squared, education, (3 dummies), union status, industry (17 dummies), region (5 dummies), part-time and firm size (3 dummies). The dependent variable is the natural logarithm of hourly wages. Regressions are run using ordinary least squares. Absolute values of t-statistics are between parentheses. The sample consists of paid workers aged 15-64 who are not full-time students and who were working at the time of the interview. The occupation indicators include 33 controls for occupation.

Source : General Social Survey of 1994

\section{Tools entered separately}

no Women yes

$0.103 \quad 0.080$

(3.76) (2.68)

$0.3352 \quad 0.3662$

$0.171 \quad 0.154$

(6.56) (5.33)

$0.3462 \quad 0.3741$
$1,754 \quad 1,754$ 
Table 5: OLS Regressions for the effect of fax use for workers who do not use computers

\begin{tabular}{|c|c|c|c|c|c|c|}
\hline Occupation Indicators & (1) & $\begin{array}{c}\text { Men } \\
\text { yes } \\
(2)\end{array}$ & (3) & (4) & $\begin{array}{c}\text { Women } \\
\text { yes } \\
(5)\end{array}$ & (6) \\
\hline Fax & $\begin{array}{l}\mathbf{0 . 1 8 1} \\
(5.09)\end{array}$ & $\begin{array}{l}\mathbf{0 . 1 1 5} \\
(3.21)\end{array}$ & $\begin{array}{l}\mathbf{0 . 1 0 7} \\
(3.00)\end{array}$ & $\begin{array}{l}\mathbf{0 . 1 3 9} \\
(2.38)\end{array}$ & $\begin{array}{l}\mathbf{0 . 1 2 8} \\
(2.17)\end{array}$ & $\begin{array}{l}\mathbf{0 . 1 2 3} \\
(2.08)\end{array}$ \\
\hline High skilled & - & $\begin{array}{l}0.135 \\
(5.35)\end{array}$ & $\begin{array}{l}0.132 \\
(5.27)\end{array}$ & - & $\begin{array}{l}0.075 \\
(1.55)\end{array}$ & $\begin{array}{l}0.074 \\
(1.54)\end{array}$ \\
\hline Top manager & - & $\begin{array}{l}0.137 \\
(1.38)\end{array}$ & $\begin{array}{l}0.150 \\
(1.52)\end{array}$ & - & $\begin{array}{l}0.056 \\
(0.36)\end{array}$ & $\begin{array}{l}0.056 \\
(0.36)\end{array}$ \\
\hline Planning & - & $\begin{array}{l}0.173 \\
(2.18)\end{array}$ & $\begin{array}{l}0.159 \\
(2.01)\end{array}$ & - & $\begin{array}{c}-0.034 \\
(0.24)\end{array}$ & $\begin{array}{l}-0.034 \\
(0.24)\end{array}$ \\
\hline Supervisor & - & $\begin{array}{l}0.098 \\
(3.00)\end{array}$ & $\begin{array}{l}0.095 \\
(2.93)\end{array}$ & - & $\begin{array}{l}0.015 \\
(0.29)\end{array}$ & $\begin{array}{l}0.016 \\
(0.30)\end{array}$ \\
\hline n emp. supervised & - & $\begin{array}{l}0.002 \\
(0.87)\end{array}$ & $\begin{array}{l}0.002 \\
(0.91)\end{array}$ & - & $\begin{array}{l}0.001 \\
(0.56)\end{array}$ & $\begin{array}{l}0.001 \\
(0.60)\end{array}$ \\
\hline married & - & - & $\begin{array}{l}0.082 \\
(2.96)\end{array}$ & - & - & $\begin{array}{l}-0.041 \\
(0.95)\end{array}$ \\
\hline Adjusted R squared & 0.5065 & 0.5371 & 0.5411 & 0.3759 & 0.3744 & 0.3743 \\
\hline Sample size & 968 & 968 & 968 & 795 & 795 & 795 \\
\hline Fax users & 137 & 137 & 137 & 129 & 129 & 129 \\
\hline $\begin{array}{l}\% \text { of fax users among workers } \\
\text { who do not use computers }\end{array}$ & $14.2 \%$ & $14.2 \%$ & $14.2 \%$ & $16.2 \%$ & $16.2 \%$ & $16.2 \%$ \\
\hline
\end{tabular}

Source : General Social Survey of 1994 
Table 6 : OLS Regressions For the Effect of Managerial Skills on Pay

\section{Men}

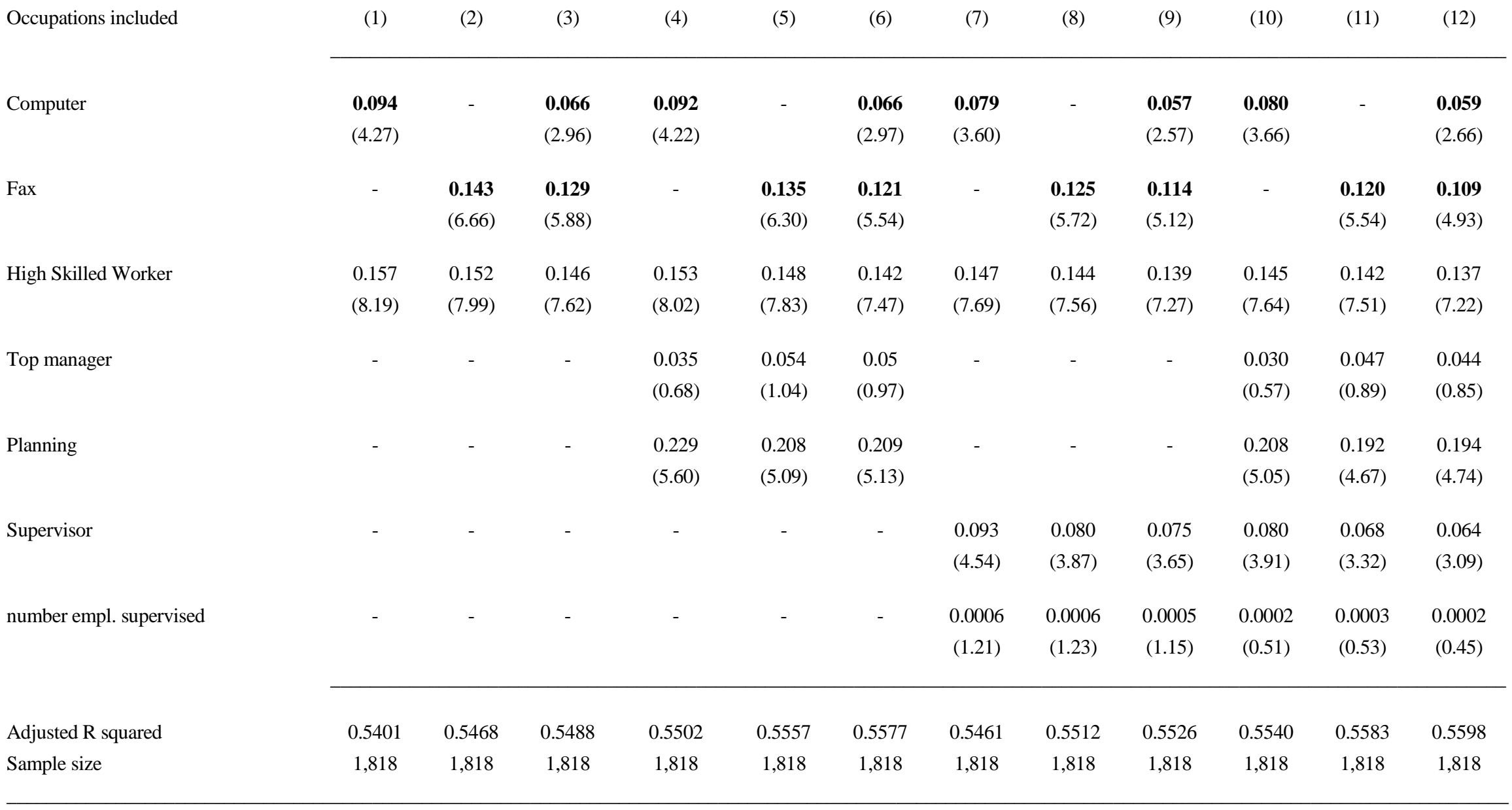

All regressions also include an intercept, age, age squared, tenure, tenure squared, education ( 3 dummies), union status, industry (17 dummies), firm size ( 3 dummies), region ( 5 dummies), part-time.

Source: General Social Survey of 1994 


\begin{tabular}{|c|c|c|c|c|c|c|c|c|c|c|c|c|}
\hline & & & & & & Women & & & & & & \\
\hline Occupations included & (1) & (2) & (3) & (4) & (5) & (6) & (7) & (8) & (9) & $(10)$ & (11) & (12) \\
\hline Computer & $\begin{array}{l}\mathbf{0 . 0 7 4} \\
(2.47)\end{array}$ & - & $\begin{array}{c}\mathbf{0 . 0 3 9} \\
(1.29)\end{array}$ & $\begin{array}{l}\mathbf{0 . 0 7 2} \\
(2.41)\end{array}$ & - & $\begin{array}{c}\mathbf{0 . 0 3 8} \\
(1.25)\end{array}$ & $\begin{array}{l}\mathbf{0 . 0 7 0} \\
(2.34)\end{array}$ & - & $\begin{array}{c}\mathbf{0 . 0 3 6} \\
(1.19)\end{array}$ & $\begin{array}{c}\mathbf{0 . 0 6 8} \\
(2.29)\end{array}$ & - & $\begin{array}{l}\mathbf{0 . 0 3 5} \\
(1.16)\end{array}$ \\
\hline Fax & - & $\begin{array}{l}\mathbf{0 . 1 4 4} \\
(4.97)\end{array}$ & $\begin{array}{l}\mathbf{0 . 1 3 5} \\
(4.49)\end{array}$ & - & $\begin{array}{l}\mathbf{0 . 1 4 3} \\
(4.90)\end{array}$ & $\begin{array}{l}\mathbf{0 . 1 3 3} \\
(4.44)\end{array}$ & - & $\begin{array}{l}\mathbf{0 . 1 4 1} \\
(4.87)\end{array}$ & $\begin{array}{l}\mathbf{0 . 1 3 3} \\
(4.43)\end{array}$ & - & $\begin{array}{c}\mathbf{0 . 1 4 0} \\
(4.82)\end{array}$ & $\begin{array}{l}\mathbf{0 . 1 3 2} \\
(4.39)\end{array}$ \\
\hline High Skilled & $\begin{array}{l}0.116 \\
(4.34)\end{array}$ & $\begin{array}{l}0.106 \\
(3.97)\end{array}$ & $\begin{array}{l}0.105 \\
(3.94)\end{array}$ & $\begin{array}{l}0.112 \\
(4.18)\end{array}$ & $\begin{array}{l}0.102 \\
(3.81)\end{array}$ & $\begin{array}{l}0.101 \\
(3.78)\end{array}$ & $\begin{array}{l}0.113 \\
(4.22)\end{array}$ & $\begin{array}{l}0.103 \\
(3.84)\end{array}$ & $\begin{array}{l}0.102 \\
(3.82)\end{array}$ & $\begin{array}{c}1.09 \\
(4.05)\end{array}$ & $\begin{array}{l}0.099 \\
(3.68)\end{array}$ & $\begin{array}{l}0.098 \\
(3.66)\end{array}$ \\
\hline Top manager & - & - & - & $\begin{array}{l}0.060 \\
(0.73)\end{array}$ & $\begin{array}{l}0.036 \\
(0.45)\end{array}$ & $\begin{array}{l}0.035 \\
(0.43)\end{array}$ & - & - & - & $\begin{array}{l}0.052 \\
(0.63)\end{array}$ & $\begin{array}{l}0.029 \\
(0.36)\end{array}$ & $\begin{array}{l}0.028 \\
(0.35)\end{array}$ \\
\hline Planning & - & - & - & $\begin{array}{l}0.101 \\
(1.59)\end{array}$ & $\begin{array}{l}0.104 \\
(1.65)\end{array}$ & $\begin{array}{l}0.103 \\
(1.63)\end{array}$ & - & - & - & $\begin{array}{l}0.093 \\
(1.46)\end{array}$ & $\begin{array}{l}0.097 \\
(1.53)\end{array}$ & $\begin{array}{c}0.096 \\
(1.51)\end{array}$ \\
\hline Supervisor & - & - & - & - & - & - & $\begin{array}{l}0.051 \\
(1.76)\end{array}$ & $\begin{array}{l}0.049 \\
(1.71)\end{array}$ & $\begin{array}{l}0.048 \\
(1.65)\end{array}$ & $\begin{array}{l}0.051 \\
(1.73)\end{array}$ & $\begin{array}{l}0.049 \\
(1.68)\end{array}$ & $\begin{array}{l}0.047 \\
(1.62)\end{array}$ \\
\hline number empl. supervised & - & - & - & - & - & - & $\begin{array}{l}0.001 \\
(0.76)\end{array}$ & $\begin{array}{l}0.001 \\
(0.73)\end{array}$ & $\begin{array}{l}0.001 \\
(0.72)\end{array}$ & $\begin{array}{l}0.001 \\
(0.54)\end{array}$ & $\begin{array}{l}0.001 \\
(0.54)\end{array}$ & $\begin{array}{l}0.001 \\
(0.54)\end{array}$ \\
\hline $\begin{array}{l}\text { Adjusted R squared } \\
\text { Sample size }\end{array}$ & $\begin{array}{c}0.3718 \\
1.749\end{array}$ & $\begin{array}{c}0.3787 \\
1.749\end{array}$ & $\begin{array}{c}0.3789 \\
1.749\end{array}$ & $\begin{array}{c}0.3725 \\
1.749\end{array}$ & $\begin{array}{c}0.3793 \\
1.749\end{array}$ & $\begin{array}{c}0.3795 \\
1.749\end{array}$ & $\begin{array}{c}0.3729 \\
1.749\end{array}$ & $\begin{array}{c}0.3797 \\
1.749\end{array}$ & $\begin{array}{c}0.3798 \\
1.749\end{array}$ & $\begin{array}{c}0.3734 \\
1.749\end{array}$ & $\begin{array}{c}0.3800 \\
1.749\end{array}$ & $\begin{array}{c}0.3801 \\
1.749\end{array}$ \\
\hline
\end{tabular}

All regressions also include an intercept, age, age squared, tenure, tenure squared, education ( 3 dummies), union status, industry (17 dummies), firm size ( 3 dummies), region (5 dummies), part-time.

Source: General Social Survey of 1994 
Table 7 : Percentage of workers who have used various computer applications in the past 12 months*

\begin{tabular}{lccc} 
Computer applications & Men & Women & All \\
Games & 47.5 & 43.2 & 45.5 \\
Word processing & 43.8 & 54.0 & 48.6 \\
Data entry & 45.5 & 53.2 & 49.1 \\
Record keeping & 41.8 & 45.4 & 43.5 \\
Data analysis & 31.2 & 25.5 & 10.0 \\
Computer programs & 11.9 & 7.9 & 10.0 \\
Internet & 11.9 & 7.9 & \\
\hline
\end{tabular}

* The numbers presented do not sum to 100 because some workers use several computer applications.

Source : General Social Survey of 1994 
Table 8: OLS Regressions for the Effect of Different Computer Applications on Pay

\begin{tabular}{|c|c|c|c|c|c|c|c|c|}
\hline \multirow{4}{*}{$\begin{array}{l}\text { Occupation } \\
\text { indicators }\end{array}$} & \multicolumn{8}{|c|}{ Applications entered together } \\
\hline & \multicolumn{4}{|c|}{ Men } & & \multicolumn{3}{|c|}{ Women } \\
\hline & (1) & (2) & (3) & (4) & $(5)$ & (6) & (7) & $(8)$ \\
\hline & no & no & yes & yes & no & no & yes & yes \\
\hline Computer & $\begin{array}{l}\mathbf{0 . 1 1 6} \\
(4.56)\end{array}$ & $\begin{array}{l}\mathbf{0 . 0 9 5} \\
(3.75)\end{array}$ & $\begin{array}{l}\mathbf{0 . 1 0 2} \\
(3.95)\end{array}$ & $\begin{array}{l}\mathbf{0 . 0 8 8} \\
(3.44)\end{array}$ & $\begin{array}{l}0.055 \\
(1.70)\end{array}$ & $\begin{array}{l}0.024 \\
(0.72)\end{array}$ & $\begin{array}{l}0.040 \\
(1.22)\end{array}$ & $\begin{array}{l}0.020 \\
(0.60)\end{array}$ \\
\hline Fax & - & $\begin{array}{l}\mathbf{0 . 1 5 6} \\
(6.97)\end{array}$ & - & $\begin{array}{l}\mathbf{0 . 1 4 6} \\
(6.34)\end{array}$ & - & $\begin{array}{l}\mathbf{0 . 1 3 4} \\
(4.63)\end{array}$ & - & $\begin{array}{l}\mathbf{0 . 1 2 3} \\
(4.02)\end{array}$ \\
\hline Games & $\begin{array}{l}\mathbf{0 . 0 4 3} \\
(1.87)\end{array}$ & $\begin{array}{l}\mathbf{0 . 0 4 5} \\
(1.99)\end{array}$ & $\begin{array}{l}\mathbf{0 . 0 3 6} \\
(1.60)\end{array}$ & $\begin{array}{l}\mathbf{0 . 0 3 8} \\
(1.73)\end{array}$ & $\begin{array}{c}-0.0006 \\
(0.026)\end{array}$ & $\begin{array}{c}0.004 \\
(0.146)\end{array}$ & $\begin{array}{l}-0.011 \\
(0.42)\end{array}$ & $\begin{array}{l}-0.008 \\
(0.29)\end{array}$ \\
\hline Word processing & $\begin{array}{c}0.0004 \\
(0.017)\end{array}$ & $\begin{array}{c}-0.011 \\
(0.43)\end{array}$ & $\begin{array}{l}0.010 \\
(0.36)\end{array}$ & $\begin{array}{l}0.002 \\
(0.06)\end{array}$ & $\begin{array}{l}\mathbf{0 . 1 3 6} \\
(4.17)\end{array}$ & $\begin{array}{l}\mathbf{0 . 1 1 1} \\
(3.39)\end{array}$ & $\begin{array}{l}\mathbf{0 . 1 4 3} \\
(4.37)\end{array}$ & $\begin{array}{l}\mathbf{0 . 1 2 7} \\
(3.86)\end{array}$ \\
\hline Data entry & $\begin{array}{r}\mathbf{- 0 . 0 4 0} \\
(1.47)\end{array}$ & $\begin{array}{c}\mathbf{- 0 . 0 5 0} \\
(1.86)\end{array}$ & $\begin{array}{r}\mathbf{- 0 . 0 2 6} \\
(0.98)\end{array}$ & $\begin{array}{r}\mathbf{- 0 . 0 3 3} \\
(1.24)\end{array}$ & $\begin{array}{c}\mathbf{- 0 . 0 5 2} \\
(1.59)\end{array}$ & $\begin{array}{r}\mathbf{- 0 . 0 5 7} \\
(1.75)\end{array}$ & $\begin{array}{r}\mathbf{- 0 . 0 3 5} \\
(1.09)\end{array}$ & $\begin{array}{r}\mathbf{- 0 . 0 3 8} \\
(1.19)\end{array}$ \\
\hline Record keeping & $\begin{array}{r}\mathbf{- 0 . 0 3 9} \\
(1.42)\end{array}$ & $\begin{array}{r}\mathbf{- 0 . 0 5 5} \\
(2.02)\end{array}$ & $\begin{array}{r}\mathbf{- 0 . 0 3 9} \\
(1.44)\end{array}$ & $\begin{array}{r}\mathbf{- 0 . 0 5 2} \\
(1.97)\end{array}$ & $\begin{array}{l}\mathbf{- 0 . 0 0 2} \\
(0.05)\end{array}$ & $\begin{array}{r}-\mathbf{0 . 0 1 1} \\
(0.33)\end{array}$ & $\begin{array}{r}\mathbf{- 0 . 0 1 4} \\
(0.42)\end{array}$ & $\begin{array}{r}\mathbf{- 0 . 0 1 9} \\
(0.57)\end{array}$ \\
\hline Data analysis & $\begin{array}{l}\mathbf{0 . 0 7 1} \\
(2.68)\end{array}$ & $\begin{array}{l}\mathbf{0 . 0 5 3} \\
(1.98)\end{array}$ & $\begin{array}{l}\mathbf{0 . 0 6 2} \\
(2.35)\end{array}$ & $\begin{array}{l}\mathbf{0 . 0 5 0} \\
(1.89)\end{array}$ & $\begin{array}{l}0.049 \\
(1.49)\end{array}$ & $\begin{array}{l}0.035 \\
(1.06)\end{array}$ & $\begin{array}{l}0.035 \\
(1.04)\end{array}$ & $\begin{array}{l}0.024 \\
(0.74)\end{array}$ \\
\hline Computer programs & $\begin{array}{l}0.012 \\
(0.38)\end{array}$ & $\begin{array}{c}0.0002 \\
(0.01)\end{array}$ & $\begin{array}{l}0.010 \\
(0.32)\end{array}$ & $\begin{array}{l}-0.005 \\
(0.16)\end{array}$ & $\begin{array}{l}0.023 \\
(0.49)\end{array}$ & $\begin{array}{l}0.040 \\
(0.83)\end{array}$ & $\begin{array}{l}0.020 \\
(0.40)\end{array}$ & $\begin{array}{l}0.025 \\
(0.52)\end{array}$ \\
\hline Internet & $\begin{array}{l}\mathbf{0 . 0 6 5} \\
(2.30)\end{array}$ & $\begin{array}{l}\mathbf{0 . 0 5 4} \\
(1.92)\end{array}$ & $\begin{array}{l}\mathbf{0 . 0 5 9} \\
(2.11)\end{array}$ & $\begin{array}{l}\mathbf{0 . 0 4 8} \\
(1.76)\end{array}$ & $\begin{array}{l}0.031 \\
(0.81)\end{array}$ & $\begin{array}{l}0.019 \\
(0.51)\end{array}$ & $\begin{array}{l}0.040 \\
(1.07)\end{array}$ & $\begin{array}{l}0.032 \\
(0.85)\end{array}$ \\
\hline Adjusted R squared & 0.4987 & 0.5117 & 0.5260 & 0.5365 & 0.3431 & 0.3508 & 0.3733 & 0.3789 \\
\hline Sample size & 1,824 & 1,824 & 1,824 & 1,824 & 1,754 & 1,754 & 1,754 & 1,754 \\
\hline
\end{tabular}

All regressions also include an intercept, age, age squared, tenure, tenure squared, education (3 dummies), union status, indust (17 dummies), firm size ( 3 dummies), region ( 5 dummies), part-time. T-statistics are between parentheses.

* Dummy variables for a given computer application equal 1 if a worker uses that particular application. For instance, column 4 suggests that computer users who do data analysis earn $15 \%$ more [i.e. exp $(0.088+0.050)-1]$ than workers who do not use computers while male fax users earn $16 \%$ more [i.e. $\exp (0.146)-1]$ than other male employees.

Source : General Social Survey of 1994. 
(1)

Age

$15-24$

25-34

$35-44$

45-54

$55-64$

\section{Education}

less than high school

graduated from high school

some post-secondary or completed

university degree

unknown

Sex

Female

Male

Part-time?

yes

no

Firm size (number of employees)

1-19

20-99

100-499

500 or more

unknown

Unionized?

yes

no

unknown
Respondents

11.8
29.4
29.8
21.3
7.8

18.4

30.6

31.4

19.6

0.1

46.3

53.7

11.9

88.1

12.4

87.6

20.6

15.4

15.7

42.5

5.7

35.1

64.7

0.2

7.8

27.6

28.6

22.9

13.1

19.6

26.5

30.7

23.2

0.1

42.8

57.2

20.8

17

14.8

34.9

12.6
(2)

Non-respondents*

* The sample consists of paid workers aged 15-64 who were not full-time students at the time of the interview. Of these individuals, $16 \%$ did not report their wage rates (non-respondents).

Source: General Social Survey of 1994 
Appendix 2 Table A1: Coefficients of logistic regressions for the probability of using a computer - Men. General Social Survey of 1994

\begin{tabular}{|c|c|c|c|c|}
\hline Explanatory variables & (1) & (2) & (3) & (4) \\
\hline \multicolumn{5}{|l|}{ Age } \\
\hline $25-34$ & $\begin{array}{c}0.672 \\
(0.175)\end{array}$ & $\begin{array}{l}0.349^{*} \\
(0.188)\end{array}$ & $\begin{array}{l}0.230^{*} \\
(0.198)\end{array}$ & $\begin{array}{c}0.191 * * \\
(0.209)\end{array}$ \\
\hline $35-44$ & $\begin{array}{c}0.931 \\
(0.175)\end{array}$ & $\begin{array}{c}0.673 \\
(0.189)\end{array}$ & $\begin{array}{c}0.507 \\
(0.200)\end{array}$ & $\begin{array}{c}0.293 * * \\
(0.210)\end{array}$ \\
\hline $45-54$ & $\begin{array}{c}0.740 \\
(0.185)\end{array}$ & $\begin{array}{c}0.620 \\
(0.201)\end{array}$ & $\begin{array}{c}0.270 * \\
(0.214)\end{array}$ & $\begin{array}{c}0.041 * * \\
(0.227)\end{array}$ \\
\hline $55-64$ & $\begin{array}{c}0.720 \\
(0.228)\end{array}$ & $\begin{array}{c}0.744 \\
(0.254)\end{array}$ & $\begin{array}{l}0.379 * \\
(0.270)\end{array}$ & $\begin{array}{c}0.247 * * \\
(0.285)\end{array}$ \\
\hline \multicolumn{5}{|l|}{ Education } \\
\hline High school & - & $\begin{array}{c}1.144 \\
(0.160)\end{array}$ & $\begin{array}{c}0.937 \\
(0.170)\end{array}$ & $\begin{array}{c}0.780 \\
(0.177)\end{array}$ \\
\hline Post-secondary & - & $\begin{array}{c}1.502 \\
(0.159)\end{array}$ & $\begin{array}{c}1.372 \\
(0.172)\end{array}$ & $\begin{array}{c}1.259 \\
(0.179)\end{array}$ \\
\hline University & - & $\begin{array}{c}3.161 \\
(0.199)\end{array}$ & $\begin{array}{c}2.099 \\
(0.223)\end{array}$ & $\begin{array}{c}1.917 \\
(0.231)\end{array}$ \\
\hline \multicolumn{5}{|l|}{ Occupation } \\
\hline Professionals/managers & - & - & $\begin{array}{c}1.900 \\
(0.149)\end{array}$ & $\begin{array}{c}1.929 \\
(0.156)\end{array}$ \\
\hline Clerical & - & - & $\begin{array}{c}1.561 \\
(0.220)\end{array}$ & $\begin{array}{c}1.196 \\
(0.225)\end{array}$ \\
\hline Sales \& Services & - & - & $\begin{array}{c}0.748 \\
(0.159)\end{array}$ & $\begin{array}{c}0.793 \\
(0.167)\end{array}$ \\
\hline Unknown & - & - & $\begin{array}{c}1.738 \\
(0.635)\end{array}$ & $\begin{array}{c}1.947 \\
(0.650)\end{array}$ \\
\hline \multicolumn{5}{|l|}{ Firm size } \\
\hline 20-99 employees & - & - & - & $\begin{array}{c}0.606 \\
(0.208)\end{array}$ \\
\hline 100-499 employees & - & - & - & $\begin{array}{c}0.850 \\
(0.211)\end{array}$ \\
\hline 500+ employees & - & - & - & $\begin{array}{c}1.635 \\
(0.178)\end{array}$ \\
\hline Unknown & - & - & - & $\begin{array}{c}0.056^{* *} \\
(0.339)\end{array}$ \\
\hline $2 \log L$ with intercept only & -2513.0 & -2513.0 & -2513.0 & -2513.0 \\
\hline $2 \log L$ & -2483.3 & -2137.9 & -1937.4 & -1816.9 \\
\hline Sample size & 1,824 & 1,824 & 1,824 & 1,824 \\
\hline
\end{tabular}

Note: Omitted groups are age $=15-24$, education = elementary or less, occupation = blue-collar, firm size $=1-19$ employees.

Standard errors are between parentheses.

Not significant at the $5 \%$ level but significant at the $10 \%$ level. Not significant at the $10 \%$ level 
Appendix 2 Table A1: Coefficients of logistic regressions for the probability of using a computer - Women General Social Survey of 1994

\begin{tabular}{|c|c|c|c|c|}
\hline Explanatory variables & (1) & (2) & (3) & (4) \\
\hline \multicolumn{5}{|l|}{ Age } \\
\hline \multirow[t]{2}{*}{$25-34$} & 0.730 & 0.705 & 0.561 & 0.542 \\
\hline & $(0.166)$ & $(0.172)$ & $(0.188)$ & $(0.192)$ \\
\hline \multirow[t]{2}{*}{$35-44$} & 0.734 & 0.838 & 0.632 & 0.585 \\
\hline & $(0.162)$ & $(0.168)$ & $(0.186)$ & $(0.189)$ \\
\hline \multirow[t]{2}{*}{$45-54$} & $0.284 *$ & 0.482 & $0.196 * *$ & $0.169 * *$ \\
\hline & $(0.169)$ & $(0.177)$ & $(0.195)$ & $(0.199)$ \\
\hline \multirow[t]{2}{*}{$55-64$} & $-0.070 * *$ & $0.290 * *$ & $0.103 * *$ & $0.089 * *$ \\
\hline & $(0.221)$ & $(0.235)$ & $(0.255)$ & $(0.261)$ \\
\hline \multicolumn{5}{|l|}{ Education } \\
\hline \multirow[t]{2}{*}{ High school } & - & 1.575 & 1.390 & 1.353 \\
\hline & & $(0.176)$ & $(0.196)$ & $(0.199)$ \\
\hline \multirow[t]{2}{*}{ Post-secondary } & - & 1.447 & 1.091 & 1.138 \\
\hline & & $(0.174)$ & $(0.198)$ & $(0.201)$ \\
\hline \multirow[t]{2}{*}{ University } & - & 2.234 & 2.040 & 1.970 \\
\hline & & $(0.195)$ & $(0.222)$ & $(0.226)$ \\
\hline \multicolumn{5}{|l|}{ Occupation } \\
\hline \multirow[t]{2}{*}{ Professionals/managers } & - & - & 1.145 & 1.089 \\
\hline & & & $(0.218)$ & $(0.222)$ \\
\hline \multirow[t]{2}{*}{ Clerical } & - & - & 2.196 & 2.153 \\
\hline & & & $(0.225)$ & $(0.230)$ \\
\hline \multirow[t]{2}{*}{ Sales \& Services } & - & - & $-0.060 * *$ & $-0.029 * *$ \\
\hline & & & $(0.235)$ & $(0.241)$ \\
\hline \multirow[t]{2}{*}{ Unknown } & - & - & $0.998 * *$ & $1.124 * *$ \\
\hline & & & $(1.268)$ & $(1.300)$ \\
\hline \multicolumn{5}{|l|}{ Firm size } \\
\hline \multirow[t]{2}{*}{ 20-99 employees } & - & - & - & $0.321 *$ \\
\hline & & & & $(0.192)$ \\
\hline \multirow[t]{2}{*}{ 100-499 employees } & - & - & - & 0.346 \\
\hline & & & & $(0.183)$ \\
\hline \multirow[t]{2}{*}{ 500+ employees } & - & - & - & 0.777 \\
\hline & & & & $(0.146)$ \\
\hline \multirow[t]{2}{*}{ unknown } & - & - & - & -0.451 \\
\hline & & & & $(0.238)$ \\
\hline $2 \log L$ with intercept only & -2405.4 & -2405.4 & -2405.4 & -2405.4 \\
\hline $2 \log L$ & -2363.5 & -2206.9 & -1966.8 & -1919.2 \\
\hline Sample size & 1,754 & 1,754 & 1,754 & 1,754 \\
\hline
\end{tabular}

Note: Omitted groups are age $=15-24$, education = elementary or less, occupation = blue-collar, firm size $=1-19$ employees.

Standard errors are between parentheses.

Not significant at the $5 \%$ level but significant at the $10 \%$ level. Not significant at the $10 \%$ level 
This paper uses data from the 1994 General Social Survey (GSS) to examine the relationship between wages and computer use.

\section{Questions on computer use :}

The specific questions relating to computer use and computer applications are:

H46 Do you use computers such as mainframes, personal computers or word processors in your job?

H47: How many hours per week do you normally use this equipment?

N3: In the last 12 months, have you done any of the following on a computer?

(a) Play games?

(b) Word processing?

(c) Data entry?

(d) Record keeping?

(e) Data analysis?

(f) Writing a computer program?

(g) Use an on-line data service such as COMPUSERVE, INTERNET or PRODIGY?

(h) Anything else?

\section{Questions on the use of a fax machine :}

The specific question relating to the use of fax machines is:

N7: In the past 12 months, did you use the following devices, at least once a week, at least once a month, less than once a month or never?

(a) Automated Banking Machine?

(b) Video Cassette Recorder?

(c) Fax Machine?

(d) Telephone answering machine?

(e) Photocopier? 


\section{Questions on wages :}

a) Reported earnings are obtained from the two following questions :

P13-1: What is your current wage or salary before deductions from all sources?

or

P13-2: What is your current wages or salary coming from the job at which you spend the most hours, before deductions from all sources?

For each of the two questions, earnings can be reported as follows :

Hourly

Daily

Weekly

Every two weeks

Twice a month

Monthly

Yearly

Other (specifiy)

No income

Don't know

Refused

P13-1 is asked to individuals who held only one job during the reference week. P13-2 is asked to multiple-job holders.

b) Weekly hours are derived from the two following questions :

If the respondent works at one job in the reference week:

$\mathrm{H} 2$ : How many hours per week do you usually work at your job?

If the respondent works at more than one job in the reference week:

H4: How many hours per week do you usually work at the job at which you spent the most hours?

c) Hourly wages are obtained by : 1) constructing hypothetical annual earnings one would obtain by working 52 weeks (e.g. multiplying monthly earnings by 12, multiplying bi-monthly earnings by 24 , etc.), 2) dividing these annual earnings by the number of weekly hours times 52 weeks. Hourly wages are those received in the main job. 


\section{Bibliography}

Allen, S.G. (1996) 'Technology and the wage structure' National Bureau of Economic Research, Working Paper no. 5534.

Autor, D.H., L.F. Katz and A.B. Krueger (1997) 'Computing inequality: have computers changed the labor market?’ National Bureau of Economic Research, Working paper no. 5956.

Baldwin, J.R., T. Gray and J. Johnson (1997) 'Technology-induced wage premia in the Canadian manufacturing plants during the 1980s.' Statistics Canada, Analytical Studies Branch, Research paper no. 92.

Bartel, A. and N. Sicherman (1997) 'Technological change and wages: an inter-industry analysis' National Bureau of Economic Research, Working paper no. 5941.

Bar-Or, Y., J. Burbidge, L. Magee and L. Robb (1995) 'The wage premium to a university education in Canada, 1971-1991', Journal of Labor Economics, Vol. 13(4), 762-794.

Beach, C.M. and G.A. Slotsve (1994) 'Polarization of earnings in the Canadian labour market' in T. Courchene (ed.), Stabilization, Growth and the Distribution Linkages in the Knowledge Era, Bell Canada Papers on Economic and Public Policy, 2, John Deutsch Institute for the Study of Economic Policy, Université Queen's, Kingston.

Bell, B.D. (1996) 'Skill-biased technical change and wages: evidence from a longitudinal data set', mimeo, Nuffield College, Oxford, July 1996.

Bound, J. and G. Johnson (1992) 'Changes in the structure of wages in the 1980s: an evaluation of alternative explanations.' American Economic Review, 82, 371-392.

Bound, J. and A.B. Krueger (1991) 'The extent of measurement error in longitudinal earnings data : do two wrongs make a right ?' Journal of Labor Economics 9, 1-24.

Dinardo, J.E. and J.S. Pischke (1997) 'The returns to computer use revisited: have pencils changed the wage structure too?' Quarterly Journal of Economics, February, 291-303.

Doms, M., T. Dunne and K.R. Troske (1997) 'Workers, wages and technology' Quarterly Journal of Economics, February, 253-290.

Dunne, T. and J.A. Schmitz Jr (1995) 'Wages, employment structure and employer size-wage premia : their relationship to advanced-technology usage at US manufacturing establishments', Economica, 62, 88-107.

Entorf, H. and F. Kramarz (1996) 'Does unmeasured ability explain the higher wages of new technology workers ?', forthcoming in European Economic Review. 
Freeman, R.B. and K. Needels (1991) 'Skill differentials in Canada in an era of rising labor market inequality’. NBER Working Paper no. 3827.

Gera, S., G. Wulong and F.C. Lee (1997) 'Information technology and labour productivity growth : an empirical analysis for Canada and the United States. Industry Canada, mimeo.

Greenan, N. and J. Mairesse (1996) 'Computers and productivity in France : some evidence'. NBER Working Paper no. 5836.

Katz, L.F. and K.M. Murphy (1992) 'Changes in relative wages, 1963-1987: supply and demand factors.' Quarterly Journal of Economics, 107(1), 35-78.

Krueger, A.B. (1993) 'How computers have changed the wage structure: evidence from microdata, 1984-1989’, Quarterly Journal of Economics, 108(1), 33-60.

Levy, F. and R.J. Murnane (1992) 'U.S. earnings levels and earnings inequality: a review of recent trends and proposed explanations', Journal of Economic Literature, 30(3), 1333-1381.

Morissette, R., J. Myles and G. Picot (1995) 'Earnings polarization in Canada, 1969-1991' in Keith G. Banting and Charles M. Beach (ed.), Labour Market Polarization and Social Policy Reform, School of Policy Studies, Queen's University.

Morissette, R. (1995) 'Why has inequality in weekly earnings increased in Canada?' Statistics Canada, Analytical Studies Branch, research paper no. 80. 